\title{
The Stock Market/Unemployment Relationship in USA, China and Japan
}

\author{
Farzad Farsio $^{1,2} \&$ Shokoofeh Fazel ${ }^{1,2}$ \\ ${ }^{1}$ Zayed University, Dubai, UAE \\ ${ }^{2}$ Montana State University-Billings, Montana, United States \\ Correspondence: Farzad Farsio, Montana State University-Billings, United States. Tel: 1-406-657-2033. E-mail: \\ ffarsio@msubillings.edu
}

Received: December 25, 2012

Accepted: January 29, 2013

Online Published: February 22, 2013

doi:10.5539/ijef.v5n3p24

URL: http://dx.doi.org/10.5539/ijef.v5n3p24

\begin{abstract}
This study investigates the relationship between unemployment rate and stock prices in USA, China and Japan; the top three world economies. Recently, there have been some articles by financial analysts asserting that unemployment rate is a strong predictor of stock prices. They refer to certain short-term periods and posit a negative causal relation from unemployment rate to stock prices. They argue that declining (rising) unemployment would display an upturn (a downturn) in the economy, an increase (a decrease) in demand for goods and services, and would therefore lead to higher (lower) profits and stock prices. In this paper, using logical analysis, we argue that these views are misleading to potential investors. We hypothesize that there is no stable long-term causal relationship from unemployment rate to stock prices. Furthermore, using quarterly data in US, China and Japan over the 1970-2011 period, we provide empirical support for our hypothesis. The empirical analysis of this paper is based on cointegration and Granger Causality tests. Our findings have one important implication: it would be a mistake to rely on unemployment rate data to make investment decisions in the stock market.
\end{abstract}

Keywords: unemployment, stock prices, causal relation

\section{Introduction}

This study focuses on the relationship between unemployment and stock prices in US, China and Japan. The objective of this study is to present logical and empirical evidence against views presented by some financial analysts (see for example, Miller, 2010 and Wojdylo, 2009) of a stable negative causal relation from unemployment rate to stock prices. These views assert that rising (falling) unemployment rates are followed by falling (rising) stock prices, and that unemployment rate can be used to predict stock prices. Referring to short-term periods, it is rationalized that rising (falling) unemployment leads to a(an) decrease (increase) in demand for goods and services, and as a result, firms' revenues, profits, and stock prices will decline (increase). In this study, we present logical and empirical evidence against these views and hypothesize that unemployment rate and stock prices do not hold any stable long-term relationship and that there is no causal effect from unemployment to stock prices. Our findings have one important implication: it would be a mistake to rely on data for unemployment rate forecasts and trends to make investment decisions in the stock market. The empirical analysis of this study is focused on US, China and Japan, covers the 1970-2011 period, and is based on cointegration, and Granger causality tests.

Many academic scholars have examined the relationship between unemployment and stock prices. Blanchard (1981) showed that in equilibrium, the same news about unemployment can sometimes be good and sometimes bad for financial assets, depending on the state of the economy. Orphanides (1992) gave empirical support for this view by showing that stock price responses to macroeconomic news may depend on the state of the economy. In particular he showed that the stock price response to unemployment news depends on the average unemployment rate during the previous year. McQueen and Roley (1993) found a strong relationship between stock prices and macroeconomic news, such as news about inflation, industrial production, and the unemployment rate based on their own definition of business conditions. However their purpose was to demonstrate the dependence of stock price responses to all macroeconomic news. Krueger (1996) studied the market rationality of bond price responses to labor market news. His focus was on the market reaction to the 
availability of more reliable information, as the unemployment data were revised. His study found that market prices were strongly affected by the unemployment announcements. Veronesi (1999), based on theoretical arguments, showed that bad news in good times and good news in bad times would generally be associated with increased uncertainty and hence an increase in the equity risk premium investors require for investing in stocks. Jagannathan and Wang (1993) found that monthly stock returns are negatively correlated with the per capita labor income growth rate. Jagannathan, Kubota and Takehara (1998) report similar findings using Japanese data. Since most of the variation in per capita labor income arises from variation in hours worked and not the wage rate, these findings are consistent with the positive correlation between the growth rate in unemployment and stock returns.

Most of the above studies attempt to display a causal relation from unemployment rate to stock prices. While either a negative or a positive correlation may exist during certain periods, it would be a mistake to assume a stable long-term causal relation from unemployment rate to stock prices. Such assumption may mislead potential investors to believe that movements in unemployment rate can predict movements in stock prices. The fact that both unemployment and stock prices are endogenous variables and that their movements depend on a variety of exogenous variables, makes it essential to conduct deeper analysis in identifying the predominant causes of movements in these variables before assuming any causal relationships. This study presents a logical analysis of the relationship and shows that no stable long-term causal relation from unemployment rate to stock prices should exist. We will then provide empirical results supporting this view. Our results have one important implication: it would be a mistake to rely on movements in unemployment rate to make investment decisions on stocks. In this paper, following logical analysis of the relationship in 2, section 3 presents methodology and empirical results which are followed by concluding remarks in section 4 .

\section{Method}

Unemployment rate and stock prices are both endogenous variables whose levels and movements depend on a variety of exogenous factors. Before positing any correlation between these endogenous variables, one should first analyze and identify exogenous factors that may affect these variables. Unemployment rate is defined as the ratio of individuals who do not have a job to total number of individuals in the in the labor force. Labor force does not include those who are not looking for a job or are unable to work. Any change in supply or demand for labor can change unemployment rate. Changes in willingness to work or ability to work will change the supply of labor and thus unemployment rate. It is important to note that changes in willingness and ability to work for already unemployed individuals do not change the actual number of working people but will change in unemployment rate. For example, if some unemployed individuals quit looking for a job or become disabled, there will be a reduction of equal amount in both numerator and denominator of the unemployment ratio, resulting in lower unemployment rate. On the other hand, changes in technology, aggregate demand, and interest rate can change the demand for labor and thus change unemployment rate.

In order to identify factors that can cause changes in stock prices, we may analyze the Discounted Cash Flow model (DCF). According to this commonly used model, a company's intrinsic value (expected share price) should be equal to the present value of its future cash flows as shown in equation (1).

$$
\mathrm{P}_{\mathrm{o}}=\mathrm{CF}_{1} /(1+\mathrm{r})+\mathrm{CF}_{2} /(1+\mathrm{r})^{2}+\ldots \ldots+\mathrm{CF}_{\mathrm{n}} /(1+\mathrm{r})^{\mathrm{n}}
$$

Where:

$\mathrm{P}_{\mathrm{o}}=$ Intrinsic Value (Expected Share Price)

$\mathrm{CF}=$ Cash Flow Per Share

$\mathrm{r}=$ Discount Rate.

The DCF model is one of the most commonly used models for stock valuation. CF represents free cash flow; cash flow available after all operating and investing needs of the firm are met. $r$ is also called the required rate of return on the stock which is most often measured by the firm's weighted average cost of capital (WACC). Based on this model, future cash flows and the discount rate that is used to calculate the present value of future cash flows are the two main factor determinants of stock prices. Higher future profits (cash flows) and/or lower discount rates (interest rates) increase stock prices. These two main factors of the stock valuation model are in turn determined by many other factors. Profit is total revenue minus total cost. Total revenue is equal to the number of units of the good the firm sells times the price of the good. The number of units sold (quantity demanded) in turn depends on the price of the good, consumers' income as well as income elasticity of demand, 
price of related products as well as their cross elasticity of demand, consumers' taste, and number of buyers of the product.

Total cost is another element affecting profits and thus the stock price. Wages and interest expenses are part of total cost. Interest rate affects stock prices through two different channels. First, it affects the discount rate that is used to estimate the present value of future cash flows. It is important to note that the discount rate (required rate of return) also depends on stock's beta coefficient and stock market's expected rate of return (CAPM). The second channel through which interest rate affects stock prices is its direct negative impact on cost of borrowing, and thus total cost, and cash flows.

In short, the list of factors that may influence the stock price of a particular company should include the following: the price of the good, consumers' income, the product's income elasticity of demand, price of related products, the product's cross elasticity of demand, consumers' taste, number of buyers of the product, interest rate, wages, other components of total cost, beta coefficient, and stock market's expected rate of return. Some of these factors can be classified as internal factors while others are grouped as external factors. For example, the product's income elasticity of demand and cross elasticity of demand are internal factors that can be controlled by the management through efforts to enhance the quality of the product and advertisement. Non-interest costs and beta coefficient are also controllable by firm's management and are therefore internal factors. On the other hand, in a competitive market, wages, price of the product, and prices of related products are determined externally by forces of demand and supply. Also, consumers' income, consumers' tastes and preferences, number of buyers (population), level of interest rates, and stock market's expected rate of return are all out of the control of managers and therefore considered external factors.

Based on the above lists of factor determinants of unemployment rate and stock prices, one could clearly deduct that there might be many situations in which a change in a factor that causes unemployment rate to change may not affect stock prices. As discussed earlier, changes in willingness and ability to work for already unemployed individuals would change the unemployment rate without changing the actual number of working people and will therefore have no impact on profits and stock prices. Even changes in technology, aggregate demand, and interest rates may not always lead to a causal relation from unemployment to stock prices. For example, one scenario in which a relationship (and not necessarily a causal relationship) may be created is when interest rates change. According to the theory of investment, all else equal, a reduction in interest rates causes an increase in firm's investment and production, increases demand for labor, and thus leads to a decline in unemployment. Lower interest rates means lowers interest expenses, lower total costs, higher profits and thus higher stock prices. In this scenario, rising stock prices would be associated with (and not caused by) falling unemployment rate. However, there are uncertainties associated with this scenario. There are ample of evidence suggesting that lower interest rates do not always lead to lower unemployment. For one thing, if firms' expectations about future profitability and the overall state of economy are not positive, no matter how low interest rates are, they may not increase their investment and as a result unemployment rate many not change at all. Even if firms' expectations are positive and they expand their investment and production, they may simply increase the working hours of current employees instead of hiring more workers. In either case, unemployment rate remains unchanged while stock prices increase. In addition to these uncertainties, there is another powerful uncertainty associated with the "all else equal" assumption. It is rare if not impossible for everything else in the economy to remain unchanged.

Given the above analysis, one could conclude that the assumption of a stable causal relation from unemployment to stock prices is illogical. Even if a short-term relationship existed in a certain period, it would not be a causal relation. Instead, it would be the result of both endogenous variables reacting to one or more exogenous factors. In short, we can posit that there is no causal relation from unemployment to stock prices. In the next section, we present the results of our empirical analysis that support this view.

\section{Results}

For US and Japan, quarterly data for unemployment rates, S\&P 500 index and the Nikkei Index from 1970-2011 were used. For China we used quarterly data for unemployment rate and the Shanghai index from 2002-2011. Data prior to 2002 were not available for China. Data for all six variables were obtained from Trading economics data base. Our empirical analysis includes three tests; the Augmented Dickey-Fuller test, the Engle-Granger cointegration test, and the Granger causality test.

\subsection{Augmented Dickey-Fuller Test}

The first step in performing the cointegration test is to test for the presence of a unit root in the individual series. To do so we employ the Augmented Dickey-Fuller test (1979). Tables 1-3 display the results of the Augmented Dickey-Fuller tests. In each case, a log polynomial in first difference of the variable was taken out six periods to 
render the residuals approximate white noise. Ljung-Box "Q" statistic was used to test the hypothesis that all of the autocorrelations are zero. For all six variables, absolute values of calculated t-statistics were lower than the MacKinnon critical values. Consequently, the null hypothesis of difference-stationary could not be rejected at any standard significance level. Although this does not prove there are unit roots in each of the variables, the consequences of specifying spurious deterministic trends convinced us that defining the variables as the first difference in the logs was the prudent way to proceed.

\subsection{Engle-Granger Cointegration Test}

The concept of correlation in a growing economy is that of common stochastic trend or cointegration. Many economic time series are not stationary. If, however, the first difference of a series is stationary, the original series is said to be integrated of order one. As described in Engle and Granger (1987), two or more variables are said to be cointegrated if individually each is non-stationary (has one or more unit roots) but there exists a linear combination of the variables that is stationary. Table 4 reports the results of the Engle-Granger test for cointegration between stock prices and unemployment rate in the three countries. The absolute value of calculated t-statistic in below the conventional MacKinnon critical values for all three countries. That is, there is no evidence of cointegration or common stochastic trends among stock prices and unemployment rate. This contradicts the view that unemployment rate and stock prices hold a stable long-run relationship. The cointegration results further confirm that unemployment rate does not have any long-run explanatory power in predicting movements in stock prices, and provide support for the hypothesis presented in this paper.

\subsection{Granger Causality Test}

In performing the Granger causality tests, the hypothesized dependent variable is regressed on its lagged values. The lag length in the regression equation must be selected in such a way that the resulting residuals are white noise, and therefore any first order serial correlations are eliminated. Next, the lagged values of the hypothesized independent variable are added to the right side of the regression equation and the new regression is executed. Using an $\mathrm{F}$ test, the resulting sums of squared residuals from the two regression equations are compared. A relatively large difference between the two sums of squared residuals (a large F) would provide evidence that the hypothesized independent variable Granger causes the dependent variable. The Granger Causality test results for the three countries are shown in Table 5. The small F statistics of the Granger Causality test (1.22,1.09, and 1.23) which are significantly lower than the critical $\mathrm{F}$ value at the 5\% confidence level (4.66 for US and Japan and 5.23 for China)) support the view that there is no causal relation from unemployment rate to stock prices in any of the three countries under the study. Our test results conform well to our logical explanations presented earlier that unemployment rate does not have any explanatory power in predicting changes in stock prices.

Table 1. Augmented Dickey-Fuller (ADF) unit root tests in USA 1970.1—2011.3

\begin{tabular}{lll}
\hline Variable & ADF Coefficient & t-stat \\
\hline S\&P 500 Index & -.005 & -.95 \\
Unemployment & -.01 & -1.86 \\
\hline
\end{tabular}

Table 2. Augmented Dickey-Fuller (ADF) unit root tests in Japan 1970.1—2011.3

\begin{tabular}{lll}
\hline Variable & ADF Coefficient & t-stat \\
\hline Nikkei Index & -.08 & -.1 .13 \\
Unemployment & -.09 & -2.01 \\
\hline MacKinnon Critical Values (167 observations) & $1 \%$ & -4.12 \\
& $5 \%$ & -3.48 \\
& $10 \%$ & -3.19 \\
\hline
\end{tabular}

Table 3. Augmented Dickey-Fuller (ADF) unit root tests in China 2002.1-2011.3

\begin{tabular}{lll}
\hline Variable & ADF Coefficient & t-stat \\
\hline Shanghai Index & -.004 & -.94 \\
Unemployment & -.01 & -2.30 \\
\hline MacKinnon Critical Values (39 observations) & $1 \%$ & -4.19 \\
& $5 \%$ & -3.68 \\
& $10 \%$ & -3.51 \\
\hline
\end{tabular}


Table 4. Cointegration test between stock prices and unemployment

\begin{tabular}{lll}
\hline Variables & Coefficient & t-stat \\
\hline S\&P, Unemployment & -.05 & -1.27 \\
Nikkei, Unemployment & -.03 & -1.12 \\
Shanghai, Unemployment & -.14 & -1.26 \\
\hline MacKinnon Critical Values & $1 \%$ & -6.32 \\
& $5 \%$ & -4.43 \\
& $10 \%$ & -3.92 \\
\hline
\end{tabular}

Table 5. Granger causality tests

\begin{tabular}{lll}
\hline Null Hypothesis: & F-Stat & Probability \\
\hline Unemployment does not cause S\&P causeS\&P S\&PTOCK PRICES S\&P & 1.22 & 0.31 \\
Unemployment does not cause Nikkei causeS\&P S\&PTOCK PRICES S\&P & 1.09 & .40 \\
Unemployment does not cause Shanghai Shanghai Shanghai Shanghai Nikkei & 1.23 & 0.30 \\
Lag:3 & & \\
\hline
\end{tabular}

\section{Conclusion}

The objective of the study was to investigate the assertion by some financial analysts that a negative casual relation exists from unemployment to stock prices, and that unemployment rate can be used to predict future stock prices. In this paper, we analyzed factor determinants of unemployment rate and stock prices, and hypothesized that there would be no stable long-term causal relationship from unemployment rate to stock prices. Furthermore, using quarterly data covering the 1970-2011 period, we provided empirical support for our hypothesis in the three largest world economies. The empirical analysis of this paper was based on cointegration and Granger Causality tests. Our findings have one important implication for investors: it would be a mistake to rely on data for unemployment rate forecasts and trends to make investment decisions in the stock market.

\section{References}

Blanchard, O. J. (1981). Output, the Stock Market, and Interest Rates. The American Economic Review, 71(1), 132-143.

Boyd, J. H., Hu, J., \& Jagannathan, R. (2005). The Stock Market's Reaction to Unemployment News: Why Bad News Is Usually Good for Stocks. Journal of Finance, 60(2), 649-672. http://dx.doi.org/10.1111/j.1540-6261.2005.00742.x

Chen, N. F., Roll, R., \& Ross, S. A. (1986). Economic forces and the stock market. Journal of Business, 59, 383-403. http://dx.doi.org/10.1086/296344

Dicky, D. A., \& Fuller, W. A. (1979). Distribution of the Estimators for Autoregressive Time Series with a Unit Root. Journal of the American Statistical Association, 74(336), 427-431.

Engle, R. F., \& Granger, C. W. J. (1987). Cointegration and Error Correction: Representation, Estimation, and Testing. Econometrica, 55, 251-276. http://dx.doi.org/10.2307/1913236

Farsio, F. F., \& Fazel, S. (2010). Does Unemployment Rate Predict Stock Prices? European Journal of Management, 10(3), 97-102.

Gertler, M., \& Grinols, E. L. (1982). Unemployment, Inflation, and Common Stock Returns. Journal of Money, Credit and Banking, 14, 216-233. http://dx.doi.org/10.2307/1991640

Jagannathan, R., \& Wang, Z. (1993). The CAPM is Alive and Well. Staff Report \#165, Federal Reserve Bank of Minneapolis.

Jagannathan, R., Kubota, K., \& Takehara, H. (1998). Relationship between Labor-Income Risk and Average Return: Empirical Evidence from the Japanese Stock Market. Journal of Business, 71(3), 319-347. http://dx.doi.org/10.1086/209747

Krueger, A. B. (1996). Do Markets Respond More to More Reliable Labor Market Data? A Test of Market Rationality. NBER Working Paper 5769.

Little, K. (Feb.10, 2010). Rising Unemployment Hurts Stocks. About.com:stocks.

McQueen, G., \& Roley, V. V. (1993). Stock Prices, News, and Business Condition. Review of Financial Studies, 
6, 683-707. http://dx.doi.org/10.1093/rfs/6.3.683

Orphanides, A. (1992). When Good News Is Bad News: Macroeconomic News and the Stock Market. Working paper, Board of Governors of the Federal Reserve System.

Veronesi, P. (1999). Stock Market Overreaction to Bad New in Good Times: A Rational Expectations Equilibrium Model. Review of Financial Studies, 12(5), 975-1007. http://dx.doi.org/10.1093/rfs/12.5.975

Wojdylo, J. (March 17, 2009). Best Prediction of the Stock Market and Economy-Unemployment rate. Subprime Blogger. 